\title{
Evaluation of the influence of manufacture parameters during organoclay synthesis
}

\section{(Avaliação da influência dos parâmetros de processo na síntese de argilas organofilicas)}

\author{
V. G. Marques ${ }^{I}$, M.R. F. Gonçalves ${ }^{l^{*}}$, A. G. Osorio ${ }^{I}$, A. B. Tessaro ${ }^{1}$, G. E. H. da Silva ${ }^{2}$, \\ G.F.R.Paganotto ${ }^{I}$, N.L.V.Carreño ${ }^{l}$ \\ ${ }^{1}$ Universidade Federal de Pelotas, Programa de Pós-Graduação em Ciência e Engenharia de Materiais, \\ Pelotas, RS, Brasil \\ ${ }^{2}$ Universidade Federal de Pelotas, Centro de Desenvolvimento Tecnológico, Engenharia de Materiais, \\ R. Gomes Carneiro 01, 96010-610, Pelotas, RS, Brasil
}

\begin{abstract}
The aim of this study was to evaluate the influences of synthesis parameters on the organophilization of a sodium bentonite clay via interlayer cation exchange by organocations. The parameters analyzed were: stirring time, rest time and surfactant concentration. The novelty of this study, when compared to others reported on the literature data, is the evaluation of different stirring and rest times, which is usually used as $20 \mathrm{~min}$ and $24 \mathrm{~h}$, respectively. The organoclays obtained were characterized via X-ray diffraction, Fourier transform infrared spectroscopy and Foster swelling test performed in water and hexane. The results allowed to observe the intercalation of the surfactant between the bentonite layers, the low influence of stirring and resting times on basal interplanar distance, and that the increase of the resting time resulted in higher efficiency on the organophilization process. The Foster swelling test evidenced the organophilic character of the obtained clay.
\end{abstract}

Keywords: organoclay, sodium bentonite, surfactant, surface modification.

Resumo

O objetivo deste trabalho foi avaliar a influência dos parâmetros de síntese de organofilização de uma bentonita sódica através da reação de troca catiônica. Os parâmetros avaliados foram: tempo de agitação, tempo de repouso e concentração do surfactante. A principal diferença desse estudo para a literatura publicada é o estudo dos tempos de agitação e de repouso. As argilas organofílicas obtidas foram caracterizadas por difração de raios X, espectroscopia de infravermelho com transformada de Fourier e teste de inchamento Foster realizado em água e hexano. Os resultados permitiram observar a intercalação do surfactante entre as camadas de bentonita, a baixa influência dos tempos de agitação e repouso e que o aumento do tempo de repouso gera maior eficiência no processo de organofilização. O teste de inchamento Foster evidenciou o caráter organofilico da argila obtida.

Palavras-chave: argila organofilica, bentonita sódica, surfactante, modificação superficial.

\section{INTRODUCTION}

Clays are raw materials composed mainly of minerals with diameter lower than $2 \mu \mathrm{m}[1]$, composed of hydrous aluminum or magnesium silicate with other elements, such as lithium, iron and potassium, showing a lamellar structure composed of tetrahedral or octahedral sheets with thickness lower than $1 \mathrm{~nm}$ and average diameter of hundreds of nanometers [2]. Besides that, they are hydrophilic and responsible for the plasticity properties [1]. The isomorphic substitution, chemical bond breaking at the edge and replacement of hydrogen $\left(\mathrm{H}^{+}\right)$to hydroxyls $\left(\mathrm{OH}^{-}\right)$in clays generate a charge instability on its crystalline structure that induces the adsorption of ions in order to stabilize the structure. The quantification of the amount of ions

*margareterfg@gmail.com exchanged in a clay is ruled by the cation exchange capacity (CEC) expressed in $\mathrm{mEq}$ per $100 \mathrm{~g}$ of clay. CEC allows a chemical modification of the clay [1], that may occur via a reaction of cations presents in an aqueous solution without the modification of the clays' crystalline structure [1,3]. A process named organophilization is one of the methods used to modify the clays' structure. This procedure consists in the insertion of organic molecules in the clays' structure, transforming the hydrophilic structure into a hydrophobic structure through the expansion of structural planes $\left(\mathrm{d}_{001}\right)$ $[1,4-6]$. In this process, the clay suffers an expansion of the mineral layers in water, followed by the addition of a surfactant. The expansion facilitates the intercalation of organic molecules between the layers. It is important to note that the final properties of the organoclay are dependent of the concentration and composition of the surfactant, as well as the stirring and rest time used in the synthesis $[5,7,8]$. 
Therefore, the optimization of some parameters is extremely important to obtain organoclays with desired properties, low cost, and high productivity. Due to its high surface area, high CEC and large capacity to swell in water, the bentonites are the most commonly used clays to synthesize organoclays [3, 5]. These clays present high expansivity, which facilitates the variation of the basal distance via the introduction of polar molecules [2]. Although calcium bentonite is easily found, the sodium bentonite has the best characteristics to exchange water molecules to inorganic cations, intercalated between the layers of the smectite $[3,5]$. Considering the importance of the process parameters to obtain organophilic clay, this study investigated the influences of surfactant concentration, stirring and rest time on the basal interplanar distance and on the hydrophobicity obtained from an organophilic sodium bentonite clay.

\section{EXPERIMENTAL}

Raw materials: natural sodium bentonite was used as raw material (henceforth called raw bentonite or raw clay), supplied by Buschle \& Lepper. Raw bentonite was dried in an oven at $100{ }^{\circ} \mathrm{C}$ for $24 \mathrm{~h}$ and sifted in a sieve ASTM \#325 (44 $\mu \mathrm{m})$ to decrease the particle size. The surfactant used was Praepagen WB (distearate dimethylammonium chloride), a quaternary salt, purchased from Clariant as a paste in an isopropanol solution that was dried at room temperature. A commercial organoclay was used to compare the results. The organophilic bentonite used was Cloisite 15A, from Southern Clay Products, with the granulometric distribution of $D_{10}=1 \mu \mathrm{m}, D_{50}=6 \mu \mathrm{m}$ and $D_{90}=13 \mu \mathrm{m}$, and basal interplanar distance $\mathrm{d}_{001}$ of $31.5 \AA$.

Organophilization of raw bentonite: the methodology used to modify the surface of sodium bentonite was the cation exchange reaction, according to [8-12]. Firstly, the raw clay delamination was performed throw a suspension of $5 \%$ of the bentonite and kept under stirring for $20 \mathrm{~min}$. Afterward, the surfactant dissolved in water was added in order to obtain a $1 \mathrm{~g} / \mathrm{mL}$ solution; this solution was stirred for 20,60 and $120 \mathrm{~min}$. The weight of surfactant used was calculated according to the capacity of ion exchange of the clay and corresponded to 100,150 and $200 \%$ of CEC. The surfactant concentration and the stirring time of the mixtures were defined based on [5], which reported the need for studies to a better understanding of this parameter. The CEC of the raw clay was determined via methylene blue test, according to ASTM C837-09 [13]. The mixture was kept resting for $24 \mathrm{~h}$ and later it was filtered and washed with distilled water to remove the excess of surfactant and chloride ions. Any solid particle retained on the filter was dried in an oven at $60{ }^{\circ} \mathrm{C}$ for $48 \mathrm{~h}$, ground and sifted at \#325 ASTM sieve (44 $\mu \mathrm{m}$ mesh size).

Characterization of the clays: the basal interplanar distance, the presence of surfactant between organoclay layers, particle size and swelling degree of the clays were evaluated. The basal interplanar distance was calculated from Bragg's law, where data needed was taken from the
X-ray diffractometry (XRD). Samples of the powders were sieved and placed in an aluminum sample door for the XRD measurements. The diffractometer used was a Bruker (D8 Advance) with accelerating voltage of $40 \mathrm{kV}$, a current of 40 $\mathrm{mA}$ and $\mathrm{CuK} \alpha$ radiation $(\lambda=1.5418 \AA$ ). The parameters used for the analyses were: step of $0.02^{\circ}$ for $0.6 \mathrm{~s} / \mathrm{step}$ and range (20) from 1.5 to $15^{\circ}$. To evaluate the resting time, a Siemens XRD (D500), voltage of $40 \mathrm{kV}$, current of $17.5 \mathrm{~mA}$ and $\mathrm{Cu}$ radiation $(\lambda=1.54056 \AA)$ were used, with the following

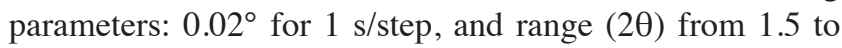
$15^{\circ}$. A Shimadzu Fourier transform infrared spectroscopy (FTIR, IR Prestige-21) was used to analyze the presence of surfactant between the layers of the clay. The range used was 4000 to $750 \mathrm{~cm}^{-1}$, and resolution of $4 \mathrm{~cm}^{-1}$. This equipment had an attenuated total reflectance (ATR) device; hence the sample was prepared as a powder. The clays particle size was measured according to the procedure described in [14]. The clay was sifted through an ASTM \#325 sieve and dispersed in a solvent, with the aid of mechanical stirring for 20 min followed by ultrasound bath. In this study, distilled water was used to disperse the bentonite and ethanol to disperse the organoclay. Then, the particle size evaluation was performed in a Cilas (1064). For the Foster swelling test, two solvents were used: water and hexane. When water was used, the methodology described in [15] was followed, where $1 \mathrm{~g}$ of clay (raw or organoclay) was slowly added to $100 \mathrm{~mL}$ of water. After $24 \mathrm{~h}$, the swelling was measured. On the other hand, the swelling test with hexane followed [16], where $1 \mathrm{~g}$ of clay (raw or organoclay) was slowly added to a graduated cylinder containing $50 \mathrm{~mL}$ of hexane (raw or organoclay). After $24 \mathrm{~h}$ of full rest, the measurement was performed for swelling with no stirring. After that, the volume contained in the graduated cylinder was stirred for 5 min with a glass stick and then the system was held for further $24 \mathrm{~h}$ to measure the swelling with stirring. Table I refers the assumptions made in $[12,16]$ to evaluate the degree of swelling of raw and organophilic clays.

Table I - Considerations for the Foster swelling test, adapted from [12].

[Tabela I - Considerações para o teste de inchamento Foster, adaptadas de [12].]

\begin{tabular}{cc}
\hline Swelling & Scale $(\mathrm{mL} / \mathrm{g})$ \\
\hline No & $\leq 4$ \\
Low & $5-8$ \\
Medium & $9-15$ \\
High & $>15$ \\
\hline
\end{tabular}

\section{RESULTS AND DISCUSSION}

Cation exchange capacity (CEC): CEC allows to evaluate the viability of the clay to be modified with a quaternary ammonium salt, because the higher its value, greater the ion exchange by surfactant ions can be achieved [10]. The bentonite showed a CEC of $135 \mathrm{mEq} / 100 \mathrm{~g}$, characteristic of 
a smectite clay, which is 80 to $150 \mathrm{mEq} / 100 \mathrm{~g}$ [3].

Basal interplanar distance: in the analysis of basal interplanar distance of bentonite and synthesized organophilic clays, it was observed the influences of surfactant concentration, stirring time and resting time. Fig. 1 presents the X-ray diffractograms of raw bentonite (Fig. 1a) and synthesized organoclay (Fig. 1b) in order to evaluate the influence of the concentration of the surfactant. Bentonite showed a basal interplanar distance of $11 \AA$, characteristic of a mineral clay 2:1. Hence, organoclay (Fig. 1b) showed varied basal interplanar distances for each surfactant concentration, $37.9 \AA$ for $100 \%$ CEC, $40.3 \AA$ for $150 \%$ CEC, and $39.3 \AA$ for $200 \%$ CEC. These results are in agreement with several reported papers $[4,9,12,17]$ when surfactant Praepagen WB was used. Nonetheless, the results obtained for basal interplanar distance $\left(\mathrm{d}_{001}\right)$ of synthesized organoclays were higher than the results published in the literature $[4,10$, $12,17]$, which indicated that the methodology used in this study provided a better arrangement of the chemical chains since a higher basal interplanar distance was achieved. The high basal distance obtained may improve the dispersion of organoclays, a factor that has a direct impact on the production of polymeric nanocomposites. The surfactant concentration that propitiated the higher basal interplanar distance was $150 \%$ CEC. The lower value obtained for $200 \%$ CEC may be attributed to the shape that surfactant molecules were arranged, where a less expanded structure was obtained; or due to a lower surfactant efficiency at higher concentrations. Besides that, an increase in basal interplanar distance when compared to bentonite indicated an effective intercalation of the surfactant. Prepared organoclays presented higher basal interplanar distance when compared to commercial Cloisite 15A organoclay $(31.5 \AA)$.
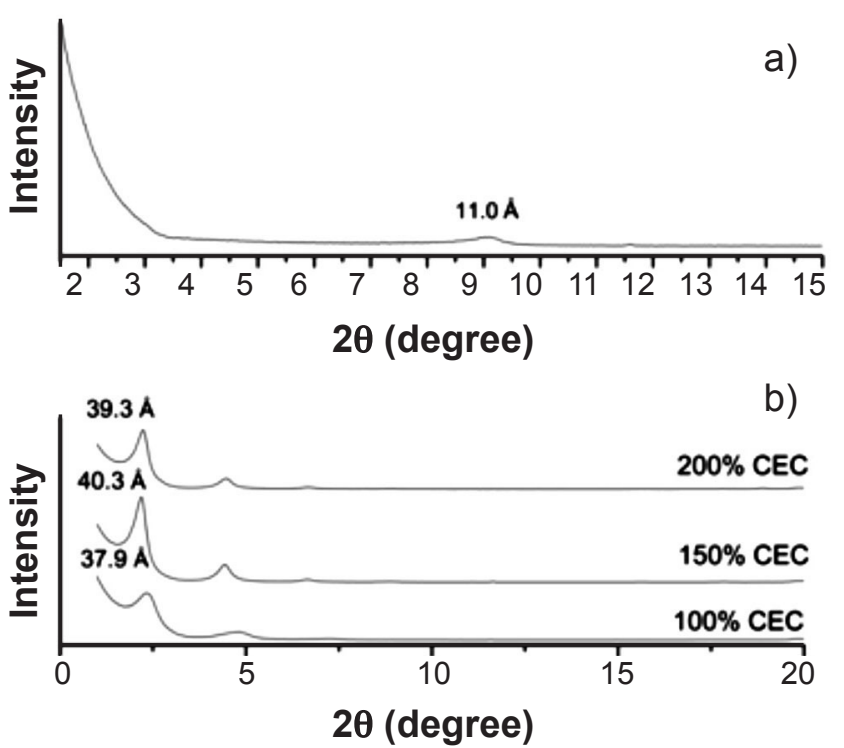

Figure 1: X-ray diffraction patterns of raw bentonite (a) and obtained organoclays with different concentrations of surfactant (b).

[Figura 1: Difratogramas de raios X da argila bentonita natural (a) e das argilas organofilicas obtidas com diferentes concentrações de surfactante (b).]
Fig. 2 presents the XRD patterns of organoclays obtained with three different concentrations of surfactant when the influence of stirring time of 20,60 and $120 \mathrm{~min}$ and resting time of $24 \mathrm{~h}$ was studied. It was noticed that the stirring time showed no influence in the basal interplanar distance of organoclays $\left(\mathrm{d}_{001}\right)$ obtained from $150 \%$ CEC of surfactant concentration (independent of the stirring time, the $\mathrm{d}_{001}$ was $40.3 \AA$ ). When $100 \%$ CEC was used, the lower basal interplanar distance was obtained when the higher stirring time was used; and whilst 200\% CEC was used the lower basal interplanar distance was obtained when the lower stirring time was used. That is, no pattern was noticed on the behavior of $\mathrm{d}_{001}$ obtained from concentrations of 100 and $200 \%$ CEC when the stirring time was varied. Hence, based on the results obtained, it was concluded that the stirring time variation had no influence in the process of organophilization, since the $1 \AA$ variation in the interplanar distance can be considered inherent to the process [14]. Comparing the results obtained with the literature values for the basal interplanar distance of bentonite (11 $\AA$ ), it was noticed that the layers showed an expansion of $336 \%$ to $366 \%$ due to the use of the surfactant, which indicated the effective intercalation of the surfactant and the obtaining of organophilic clays.

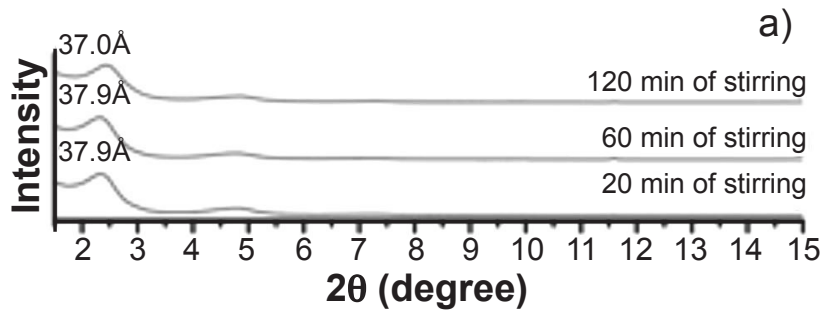

b)
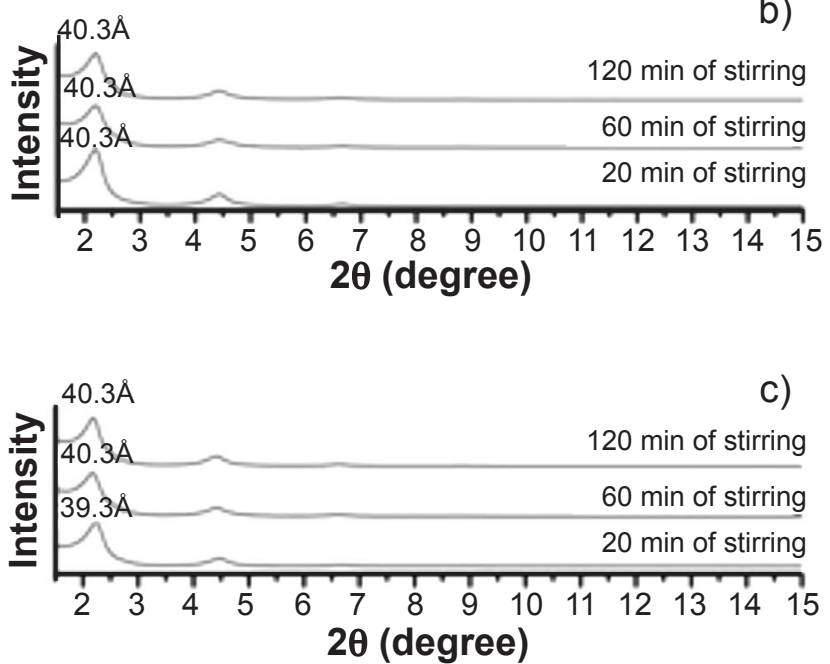

Figure 2: X-ray diffraction patterns of the obtained organoclays with surfactant concentration of: (a) 100\% CEC; (b) 150\% CEC; and (c) $200 \%$ CEC.

[Figura 2: Difratogramas de raios $X$ das argilas organofilicas obtidas com concentração do surfactante de: (a) 100\% CTC; (b) $150 \%$ CTC; e (c) $200 \%$ CTC.]

To evaluate the influence of resting time after the 
organoclay synthesis, the lower stirring time (20 $\mathrm{min}$ ) was used, as well as the surfactant concentration of $150 \%$ CEC, since this concentration presented the highest basal interplanar distance. Samples were evaluated with no resting time and with 12, 36 and $48 \mathrm{~h}$ of rest, and were compared with the organoclay commonly rested for $24 \mathrm{~h}$. The X-ray diffraction patterns in Fig. 3 indicated that there was an increase of the basal interplanar distance according to the resting time, until $24 \mathrm{~h}$; afterward, no influence was evidenced on the basal interplanar distance and hence there was no need to extend the rest time to reach the reaction equilibrium. This result was compatible with others reported in the literature. Ferreira et al. [8] studied the resting time in organophilization process for 24 and $96 \mathrm{~h}$, obtaining better results for $24 \mathrm{~h}$ of resting time. However, when basal interplanar distance was compared to bentonite, the results showed an increase in its value, which indicated the obtaining of an organophilic clay with $\mathrm{d}_{001}$ of $40.05 \pm 0.25 \AA$.

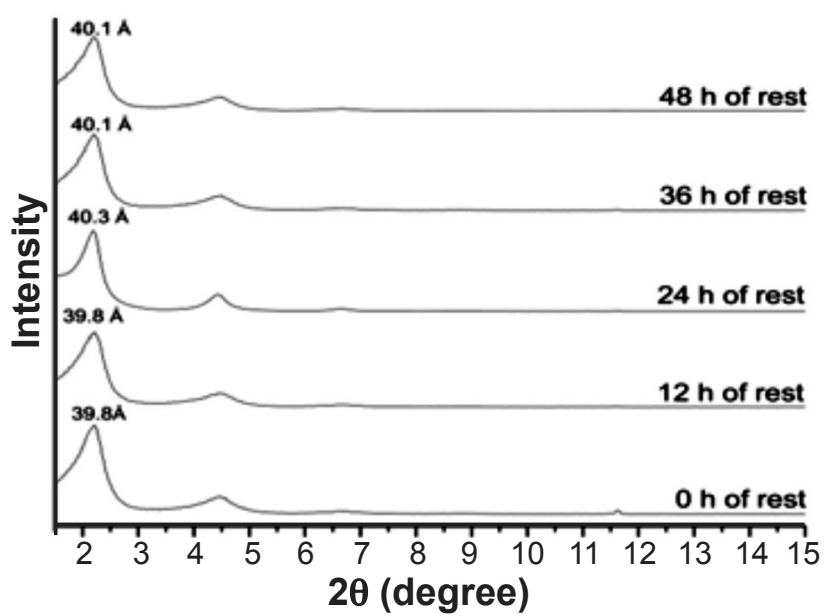

Figure 3: X-ray diffraction patterns of organoclays with stirring time of $20 \mathrm{~min}$, a surfactant concentration of $150 \%$ CEC and various resting times.

[Figura 3: Difratogramas de raios $X$ das argilas organofílicas obtidas com 20 min de agitação, surfactante na concentração de $150 \%$ CTC e diferentes tempos de repouso.]

Evaluation of the surfactant between layers: Fig. 4 illustrates the infrared spectra of bentonite and the surfactant. Fig. 4a presents a band at $3620 \mathrm{~cm}^{-1}$ that can be attributed to the vibration frequency of hydroxyl groups, characteristics of the clay, a band at $1634 \mathrm{~cm}^{-1}$ that can be attributed to the adsorbed water, and a band at $989 \mathrm{~cm}^{-1}$, characteristic of the octahedral layers of the clay. There were still other bands characteristics of the clays that may be overlapped (around $1007 \mathrm{~cm}^{-1}$, attributed to Si-O-Si link, and $767 \mathrm{~cm}^{-1}$, attributed to the octahedral layers). In Fig. $4 \mathrm{~b}$ it is possible to observe bands at 2914 and $2849 \mathrm{~cm}^{-1}$, characteristics of distearyl dimethylammonium chloride salt that can be attributed to asymmetric and symmetric vibrations of the $\mathrm{CH}_{2}$ group, respectively, and the band at $1470 \mathrm{~cm}^{-1}$ that can be attributed to the angular deformation of the $\mathrm{CH}_{2}$ group.

Fig. 5 illustrates FTIR spectra of organoclays obtained
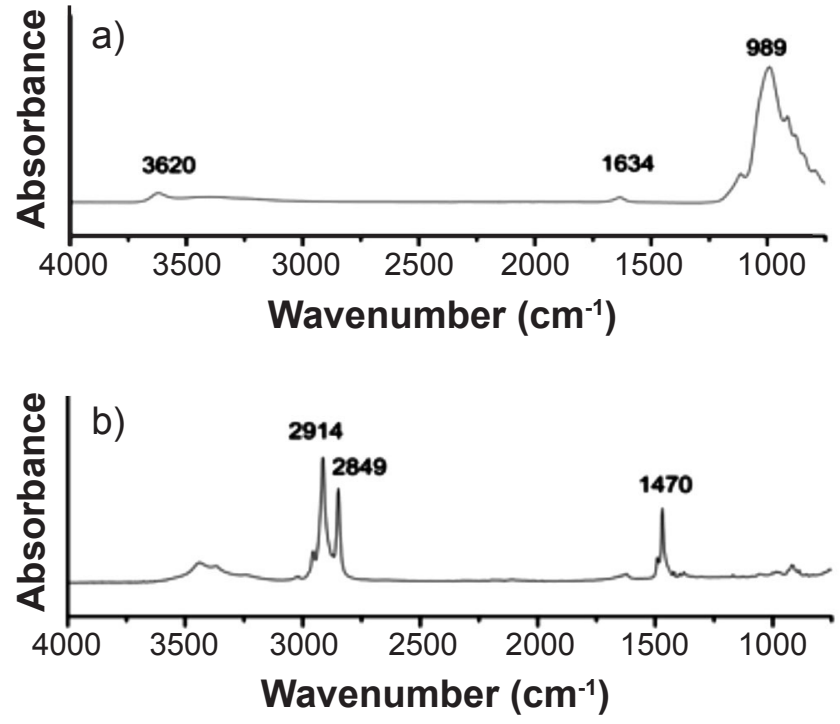

Figure 4: FTIR spectra of bentonite (a) and surfactant Praepagen WB (b).

[Figura 4: Espectros de infravermelho com transformada de Fourier da argila natural (a) e do surfactante Praepagen WB (b).]

for different surfactant concentrations and stirring times, keeping $24 \mathrm{~h}$ of resting time. Fig. 6 presents the FTIR spectra obtained for different resting times. For all spectra obtained for different surfactant concentrations, stirring and resting times, absorption bands were seen at 2914-
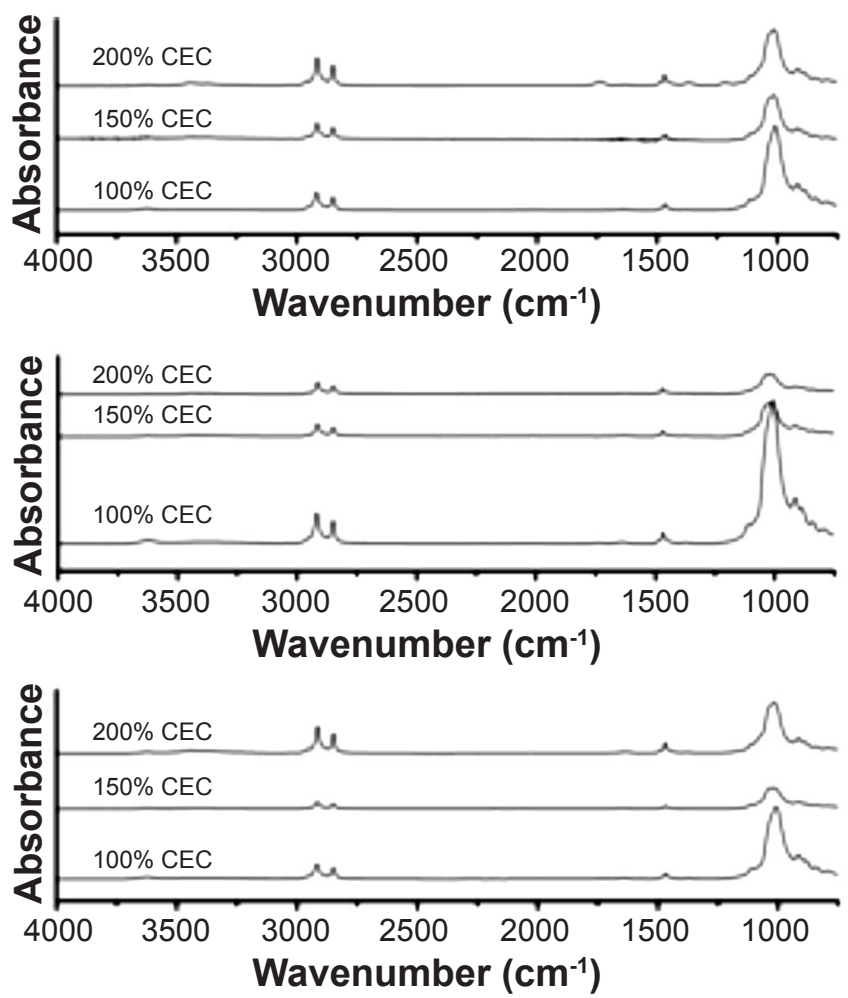

Figure 5: FTIR spectra obtained for organoclays in stirring times of: (a) $20 \mathrm{~min}$; (b) $60 \mathrm{~min}$; and (c) $120 \mathrm{~min}$.

[Figura 5: Espectros de infravermelho das argilas organofilicas obtidas em diferentes tempos de agitação de: (a) $20 \mathrm{~min}$; (b) 60 min; e (c) 120 min.] 
Table II - Particle size distribution data of raw bentonite and synthesized organoclays. [Tabela II - Dados de distribuição de tamanho de partícula da bentonita natural e das argilas organofilizadas.]

\begin{tabular}{|c|c|c|c|c|}
\hline & Sample & $\mathrm{D}_{10}(\mu \mathrm{m})$ & $\mathrm{D}_{50}(\mu \mathrm{m})$ & $\mathrm{D}_{90}(\mu \mathrm{m})$ \\
\hline \multirow{10}{*}{$\begin{array}{l}\text { Organo- } \\
\text { bentonite }\end{array}$} & Raw bentonite & 0.92 & 2.48 & 7.29 \\
\hline & $100 \%$ CEC, 20 min & 3.83 & 13.19 & 34.54 \\
\hline & $100 \%$ CEC, $60 \mathrm{~min}$ & 4.55 & 14.79 & 34.61 \\
\hline & $100 \% \mathrm{CEC}, 120 \mathrm{~min}$ & 3.40 & 12.16 & 34.27 \\
\hline & $150 \%$ CEC, $20 \mathrm{~min}$ & 5.11 & 15.63 & 33.22 \\
\hline & $150 \%$ CEC, $60 \mathrm{~min}$ & 5.22 & 18.93 & 42.08 \\
\hline & $150 \% \mathrm{CEC}, 120 \mathrm{~min}$ & 5.14 & 15.49 & 34.51 \\
\hline & $200 \%$ CEC, $20 \mathrm{~min}$ & 5.55 & 15.92 & 32.98 \\
\hline & $200 \%$ CEC, $60 \mathrm{~min}$ & 5.57 & 14.33 & 23.80 \\
\hline & $200 \%$ CEC, $120 \mathrm{~min}$ & 5.38 & 15.32 & 30.99 \\
\hline
\end{tabular}

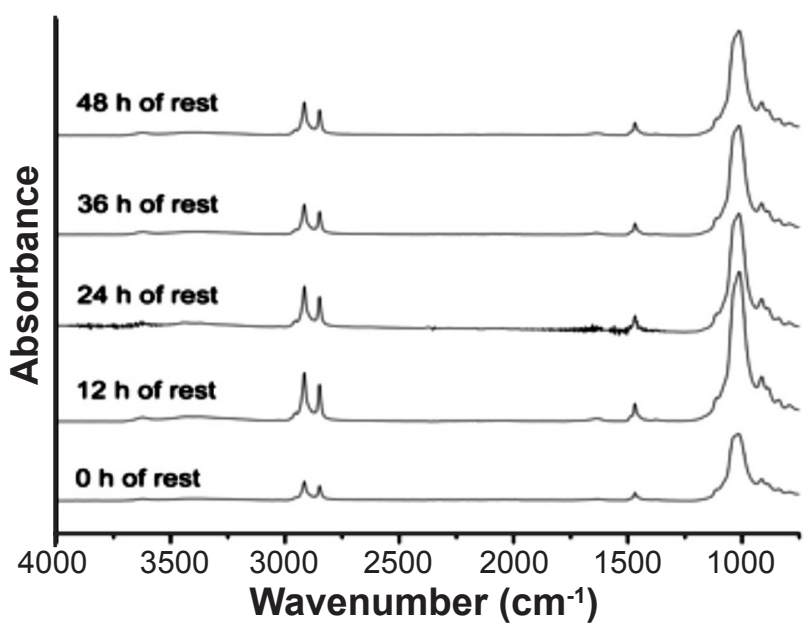

Figure 6: FTIR spectra of the obtained organoclays for various resting times.

[Figura 6: Espectros de infravermelho das argilas organofilicas com diferentes tempos de repouso.]

2916 and $2849 \mathrm{~cm}^{-1}$, corresponding to the asymmetric and symmetric vibrations of $\mathrm{CH}_{2}$ group, as well as the band at $1468-1470 \mathrm{~cm}^{-1}$, attributed to the angular deformation of the $\mathrm{CH}_{2}$ group, characteristic of a quaternary ammonium salt. These results confirmed the presence of surfactant in the clay. Bands at lower frequencies were also seen (lower than $1200 \mathrm{~cm}^{-1}$ ), that are characteristic of bentonite, which indicated that the clay's structure was not modified. In addition, it was possible to observe a decrease of the bands at $1634 \mathrm{~cm}^{-1}$, characteristics of adsorbed water, which indicated that organoclays obtained showed a hydrophobic behavior.

Particle size: the results obtained for particle size distribution of organoclays synthesized with different surfactant concentrations and stirring times, with $24 \mathrm{~h}$ of rest are described in Table II, as well as the results of particle size obtained for raw bentonite. Particle size distribution results indicated that the increase in the surfactant concentration increased the granulometric distribution of
Table III - Particle size distribution data of organoclays obtained with $150 \%$ CEC of surfactant, 20 min of stirring time and different resting times $(0,12,24,36$ and $48 \mathrm{~h})$. [Tabela III - Dados de distribuição de tamanho de partícula das argilas organofilicas com surfactante na concentração de $150 \%$ do CTC, 20 min de tempo de agitação e diferentes tempos de repouso $(0,12,24,36$, e $48 \mathrm{~h})$.]

\begin{tabular}{cccc}
\hline Sample & $\mathrm{D}_{10}(\mu \mathrm{m})$ & $\mathrm{D}_{50}(\mu \mathrm{m})$ & $\mathrm{D}_{90}(\mu \mathrm{m})$ \\
\hline $0 \mathrm{~h}$ & 4.90 & 16.42 & 37.24 \\
$12 \mathrm{~h}$ & 4.81 & 16.33 & 37.50 \\
$24 \mathrm{~h}$ & 5.11 & 15.63 & 33.22 \\
$36 \mathrm{~h}$ & 4.55 & 15.97 & 37.93 \\
$48 \mathrm{~h}$ & 4.19 & 14.08 & 33.81 \\
\hline
\end{tabular}

the synthesized organoclays, leading to the formation of agglomerates of the raw bentonite, behavior also observed in [14]. However, the agglomeration indicated that raw bentonite may be associated to a non-efficient dispersion of bentonite during the synthesis; water was used to disperse raw bentonite (solvent known to be a good dispersant of sodium bentonite), while ethanol was used for dispersion of organoclay. For the basal interplanar distance of organoclays with different resting times used $(0,12,24,36$ and $48 \mathrm{~h})$, the results presented on Table III indicated that the rest time after the insertion of surfactant showed no influence on the organoclay particle size.

Swelling degree: Fig. 7 present the obtained results during the Foster swelling test using water and hexane as a solvent for raw bentonite and commercial organoclays (Cloisite 15A), respectively; hexane was also used for organoclays obtained with different surfactant concentrations and stirring time, keeping the resting time of $24 \mathrm{~h}$. When hexane was used as a solvent, the swelling was measured with and without stirring. The swelling value obtained for raw sodium bentonite (Fig. 7a) was $21 \mathrm{~mL} / \mathrm{g}$, indicating an increase of 13 times in volume, expansion attributed to the smectites. 

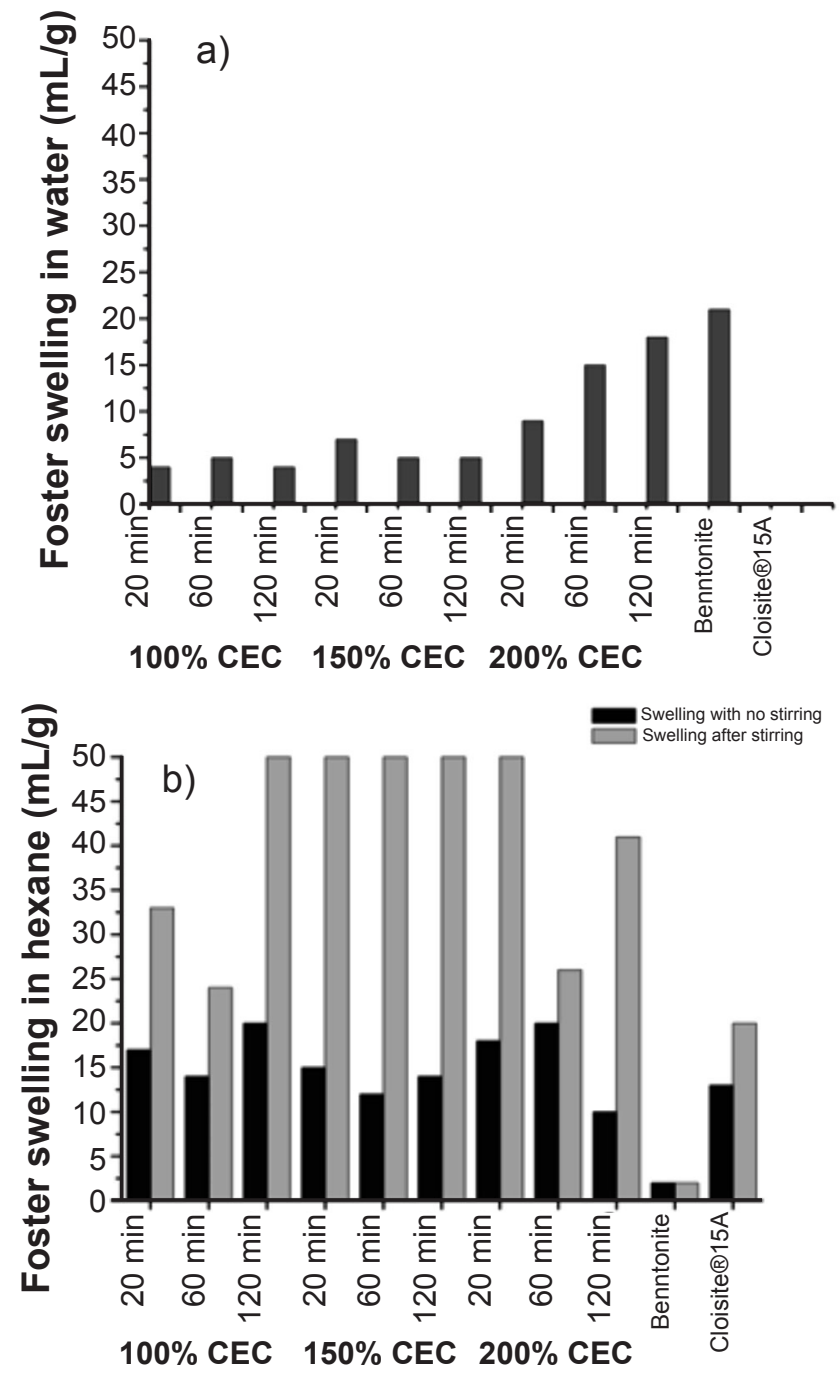

Figure 7: Foster swelling using: (a) water as a solvent; and (b) hexane as a solvent without and after stirring.

[Figura 7: Inchamento Foster usando: (a) água como solvente; e (b) hexano como solvente, antes e após agitação.]

The results in Fig. 7a also shows that all clays (raw and organophilic) absorbed water, indicating that they were not totally hydrophobic as the commercial clay Cloisite 15A, used as a standard in this study. It is proposed that this result indicates that there may be a remaining fraction of raw sodium bentonite, which keeps them dispersed in water. In addition, one can observe that the increase of surfactant concentration tended to increase the swelling, and the stirring time showed no standard behavior when compared to the swelling variation evidenced in Fig. 7a.

The higher values of swelling for organoclays tested was seen for the concentration of 200\% CEC (value near the one obtained for raw bentonite, $21 \mathrm{~mL} / \mathrm{g}$ ), using stirring times of 60 and $120 \mathrm{~min}$. This result may indicate that a large fraction of clay remained as sodium bentonite, with no intercalation of the ammonium quaternary salt between the layers; nonetheless, the peak characteristic of sodium bentonite $\left(8.1^{\circ} 2 \theta\right)$ was not seen in the XRD results, which indicated that the high swelling may be caused by a large number of voids in the structure of the clay, responsible for the high basal interplanar distance ( $40.3 \AA)$. Fig. $7 b$ presents the results obtained during the swelling test in hexane. When stirring was not used, the value was $9 \mathrm{~mL} / \mathrm{g}$, related to the clay obtained with a surfactant concentration of $200 \%$ CEC and $120 \mathrm{~min}$ of stirring time. Whereas the higher value obtained was $20 \mathrm{~mL} / \mathrm{g}$ (high swelling, according to Table I), related to the clay obtained with a surfactant concentration of $200 \%$ CEC and $60 \mathrm{~min}$ of stirring time. When stirring was used, the swelling test reached $50 \mathrm{~mL} / \mathrm{g}$, being labeled as total, for the surfactant concentration of $150 \% \mathrm{CEC}$, i.e., these organoclays presented high dispersion in the solvent used, indicating high affinity with the apolar organic solvent. The total dispersion was also obtained with a concentration of $100 \%$ CEC and $120 \mathrm{~min}$ of stirring time and at 200\% CEC and 20 min of stirring time. Raw bentonite did not present any swelling with or without stirring, which evidenced its organophobic character; the commercial organoclay showed a swelling of $13 \mathrm{~mL} / \mathrm{g}$ without stirring (medium swelling, according to Table I) and $20 \mathrm{~mL} / \mathrm{g}$ with stirring (high swelling, according to Table I).

The organoclay analysis using surfactant concentration of $150 \%$ CEC at $20 \mathrm{~min}$ of stirring time, at steady times of $0,12,24,36$ and $48 \mathrm{~h}$, can be seen in Fig. 8. All organoclays showed values of swelling in water considered as irrelevant (according to Table I), with exception of the organoclay rested for $24 \mathrm{~h}$. This may be caused by the presence of voids in the structure, which facilitated water trapping. Evaluating the swelling results with hexane (Fig. 8), a larger difference was observed with resting time of $12 \mathrm{~h}$, with values lower than $9 \mathrm{~mL} / \mathrm{g}$ (Table I), whereas all the other samples showed values of $14 \pm 2 \mathrm{~mL} / \mathrm{g}$ considered medium swelling (exception to test without steady time, that presented high swelling, according to Table I). When tests were performed with stirring, the total swelling was obtained, except for tests performed without the steady time and with a steady time

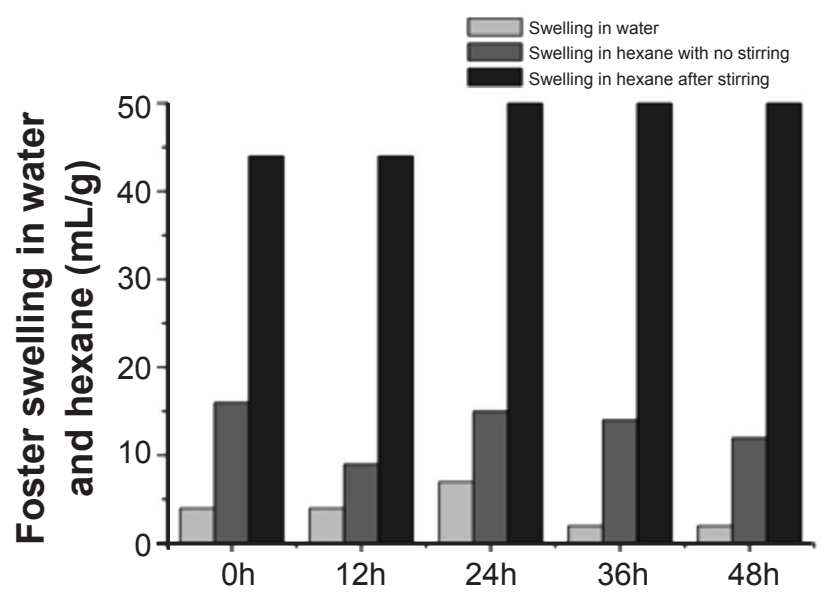

Figure 8: Foster swelling of the organoclay with a surfactant concentration of $150 \% \mathrm{CEC}$, at $20 \mathrm{~min}$ of stirring time and different resting times.

[Figura 8: Inchamento Foster das argilas organofilicas com surfactante na concentração de $150 \%$ de CTC, 20 min de agitação e diferentes tempos de repouso.] 
of $12 \mathrm{~h}$ (nearly total swelling of $44 \mathrm{~mL} / \mathrm{g}$ ). This result was attributed to the high chemical affinity of surfactant used to modify the clays with the organic solvent used.

\section{CONCLUSIONS}

In this work, different organophilic clays were successfully obtained. Different synthesis parameters were evaluated, such as surfactant concentration, stirring time and resting time. A higher basal interplanar distance and hydrophobicity degree were obtained for the organoclay with a surfactant concentration of $150 \%$ CEC, 20 min of stirring time and rest time of $36 \mathrm{~h}$. Also, the organoclays showed higher basal interplanar distance when compared to the literature. Results for Foster swelling test in water and hexane showed that the increase in surfactant concentration led to an increase of the water swelling. These results also indicated a swelling variation, according to the stirring time, although, this variation was not regular. In addition, the increase in resting time led to a higher degree of hydrophobicity. Besides that, it was possible to observe by the Foster swelling test that the obtained clays presented organophilic behavior in hexane, as expected for organophilic clays. When comparing the organoclays obtained with the commercial clay Cloisite 15A, the larger basal interplanar distance was achieved $(17.5 \%$ to $28 \%$ larger), and a higher degree of dispersion at the organic solvent although the obtained clays had partial hydrophobic character. The particle size for the organoclays was similar to the commercial clay. The organoclays synthesized in this work have the potential to be applied in polymeric composites due to their high basal spacing verified, that can facilitate the intercalation of the polymer. Besides that, the organoclays can be effective in effluent treatments with organic contaminants due to the fact that they are not repelled by water and have high interlamellar distance.

\section{ACKNOWLEDGEMENTS}

The authors would like to acknowledge the Electronic Microscopy Center (CEME-SUL/ FURG), the Institute of Physics of UFRGS and the CDCBio from UFPel for the results performed in these centers. The author would also like to thank the Coordination for the Improvement of
Higher Education Personnel (CAPES) for the funding of the research.

\section{REFERENCES}

[1] E. Teixeira-Neto, A.A. Teixeira-Neto, Quím. Nova 32, 3 (2009) 809.

[2] A.C.V. Coelho, P.S. Santos, Quím. Nova 30, 5 (2007) 1282 .

[3] P.S. Santos, Ciência e tecnologia de argilas, $2^{\text {nd }}$ Ed., Edgar Blucher, S. Paulo (1989).

[4] R. Barbosa, A.D. de Oliveira, T.J.A. de Melo, Cerâmica 52, 324 (2006) 264.

[5] L.B. de Paiva, A.R. Morales, F.R.V. Díaz, Appl. Clay Sci. 42, 1-2 (2008) 8.

[6] V. Mittal, Polymer nanocomposite foams, CRC Press, New York (2014).

[7] K.R.O. Pereira, M.G.F. Rodrigues, F.R.V. Díaz, Rev. Eletr. Mater. Proc. 2.2 (2007) 1.

[8] H.S. Ferreira, L.F.A. Campos, R.R. Menezes, J.M. Cartaxo, L.N.L. Santana, G.A. Neves, H.C. Ferreira, Cerâmica 59, 350 (2013) 277.

[9] E.M. Araújo, T.J.A. de Melo, A.D. de Oliveira, H.L.D. Araújo, K.D. Araújo, R. Barbosa, Polímeros 16, 1 (2006) 38. [10] R.R. Menezes, M.M. Ávila Júnior, L.N.L. Santana, G.A. Neves, H.C. Ferreira, Cerâmica 54, 330 (2008) 152.

[11] W.H. Hoidy, M.B. Ahmad, E.A. Jaffar, A. Mulla, N.A.B. Ibrahim, Am. J. Appl. Sci. 6, 8 (2009) 1567.

[12] L.B. Paiva, A.R. Morales, Braz. J. Chem. Eng. 29, 03 (2012) 525 .

[13] Am. Soc. Test. Mater., ASTM C837-09: "Standard test method for methylene blue index of clay" (2014).

[14] H.S. Ferreira, "Otimização do processo de organofilização de bentonitas visando seu uso em fluidos de perfuração não aquosos", $\mathrm{PhD}$ Thesis, Un. Fed. Campina Grande, Campina Grande (2009).

[15] M.D. Foster, Am. Mineral 38 (1943) 994.

[16] F.R.V. Díaz, "Preparação em nível de laboratório de algumas argilas esmectíticas organofílicas", $\mathrm{PhD}$ Thesis, Un. S. Paulo, S. Paulo (1994).

[17] H.S. Ferreira, R.R. Menezes, H.S. Ferreira, A.B. Martins, G.A. Neves, H.C. Ferreira, Cerâmica 54, 329 (2008) 77.

(Rec. 02/10/2017, Rev. 02/01/2018, 15/02/2018, Ac. 16/02/2018) 